\title{
Studies on weed diversity and its associated phytosociology under direct dry seeded rice systems in Koria District (C.G.) India
}

\begin{abstract}
Chhattisgarh is commonly known as Bowl of rice where rice is grown as monocarp in the entire state whether soil is bhata, matasi, kanhar or black soil. Present study is based on the study of biodiversity of weeds under Direct Dry Seeded Rice Systems in Koria District (C.G.) Study was conducted to assess the phytosociological studies of weed species in paddy field at Baikunthpur, Koria district, Chhattisgarh. A total of 43 genera and 09 families of Dicotyledonae and 03 families of monocots \& one Pteridophytes was also observed and 43 weed species were identified Ratio of Sedges: (Grasses: Broad-leaved weeds was calculated as 9:12:18 Ratio) under Direct Dry Seeded Rice Systems. The results obtained indicated that Echinochloa colona, Cyperus iria and Cynodon dactylon were the most frequent in 200; Echinochloa colon and Cyprus iria were the most frequent in 2008 and 2009. The importance value index (IVI) revealed that the most important weeds within the community were Poaceae and cyperaceous. Out of 12 angiospermic families the predominance was shown by monocot families Cyperaceae and Poaceae having and weeds species, respectively. The pteridophytic family Marsileaceae was represented by 01 weed species.
\end{abstract}

Keywords: weed, paddy cropping system, diversity, koria chhattisgarh
Volume 7 Issue 2 - 2017

\author{
Mantosh Kumar Sinha \\ Principal, KR Technical College, Sarguja University, India
}

Correspondence: Mantosh Kumar Sinha, Principal, KR Technical College, Pt. Shivdhari Colony, Near Forest Office Pratappur Road,Ambikapur (C.G.), India,Tel 085 I8860388, 09691610059, Email sinha.mantosh80@gmail.com

Received: July 20, 2016 | Published: May 24, 2017

\section{Introduction}

Agriculture has been a forefront agenda at national and internationa level for food security and management of natural resources. Cereals are the most important part of our diet throughout the world and thus, play major role in our food security. Crop paddy (Oryza sativa L.) has been an important crop which is extensively grown in tropical and subtropical regions of the world. It is cultivated in area of 44.0 million hectares with an annual production of 104.3 million tons in India. ${ }^{1}$ Its production has been found to be distributed as 91.5 million tons in kharif and 12.8 million tons in rabi season. However, its productivity in India is very low $\left(2.37 \mathrm{tha}^{-1}\right)$ as compared to other rice growing countries like Japan $\left(6.35 \mathrm{t} \mathrm{ha}^{-1}\right)$, Australia $\left(6.22 \mathrm{t} \mathrm{ha}^{-1}\right)$, Spain $(6.16 \mathrm{t}$ $\left.\mathrm{ha}^{-1}\right)$, Egypt $\left(5.0 \mathrm{t} \mathrm{ha}^{-1}\right)$ and China $\left(5.2 \mathrm{tha}^{-1}\right)$. There are several reasons for its low productivity but the losses due to weeds are one of the most important. Paddy (Oryza sativa L.) is one of the most important food crops of the world and is the second emerging crop in India after wheat. India is the second largest producer of rice after China. ${ }^{2}$ Beside its use for human food, paddy is a source for number of industrial products like rice starch, rice bran oil, flaked rice, puffed rice and rice husk etc. Being staple food it plays an important role in the economy of India hence occupies a central position in agricultural policy making. ${ }^{3}$ Weed is a plant which is judged by man to be not of use and undesirable at a place where it flourishes. ${ }^{4}$ The weeds that grow along with paddy crop results in low agricultural output. They are the major barriers to rice production because of their ability to compete for $\mathrm{CO}_{2}$, space, moisture, sunlight and nutrients. Weedy crop sometimes leads to complete failure. ${ }^{5}$ Out of total losses due to various biotic factors weeds are known to account for one third. ${ }^{6}$ It has been observed that grain yield in paddy is drastically reduced if it is not de weeded at early stage of growth. Biogeographically, Chhattisgarh state falls in Deccan bio-region comprising representative fauna of central India. Chhattisgarh used to produce over seventy percent of the total paddy production in the state. Apart from paddy, cereals like maize, Kodo- kutki and other small millets, pulses like Tur and Kulthi and oil seeds like groundnut, soya bean, Niger and sunflower are also grown. Koria exhibits a very high temperature and assumes ecological importance for an extensive survey of cultivated fields, especially paddy crop. Rice is the first important crop of this area. In Chhattisgarh, rice is a widely grown crop. The type of rice culture used by a common farmer is generally "dry seeded". The dry seeded rice suffers a lot by heavy weed infestations. Therefore, the management of weeds in dry seeded rice was thought as a must. Other aspects, such as, Phytosociology, phenology, ecology and reciprocal relations of direct seeded rice fieldweeds and crop needs to be studied as thoroughly as possible. Directseeded rice suffers more by weed infestation than the transplanted rice. Apart from the various traditional methods of weed control, crop suffers a lot by weeds. The extent of damage depends upon the nature of weeds, their density, dominance, ecological success and the association with the crops and other biotic and edaphic factors. It is, therefore, necessary to make a detailed survey of weeds in crop fields, their distribution, and relative occurrence in specific crops. Therefore, there is a great need of research aiming at prevention of loss of yield due to weeds in direct-seeded rice and at management of weeds by most economic and feasible method. These objectives can be achieved through a better understanding of biology of different weeds infesting direct-seeded rice fields.

\section{Materials and methods}

\section{Methodology}

The present study deals with major weeds of paddy fields of Shivpur, Tilpandand, Itga, Rakiya, and Jamgahna under Baikunthpur block of Koria district (C.G). The study was based on extensive and intensive fields surveys during the peak period of weed growth during three successive cropping seasons from 2007-2009. Frequent field trips were made twice a month in each site for collection of weed species. During this course interviews were conducted from farmers 
and agriculturalists of each site about seasonal weed species and important notes on flowering and fruiting seasons of weeds were reported. The collected weed plants were pressed, dried, preserved and properly identified with the help of available literature and monographs by Sharma et al., ${ }^{7}$ Swami et al., ${ }^{8} \mathrm{Kaul}^{9}$ and confirmed from the authentic regional herbaria at Botanical Survey of India.

\section{Quadrate and phytosociological studies}

$1 \mathrm{~m} \times 1 \mathrm{~m}$ Quadrats were laid in the agricultural fields to quantify various weed species. The size of the quadrate used in this study was decided based on the species area curve method following Misra (1968). The structure and composition of vegetation in the agricultural fields have been compared in terms of frequency, density, abundance, and basal area of major species. Importance Value Index (IVI=relative frequency + relative density + relative dominance) and species diversity index $\left(\mathrm{H}^{\prime}=\mathrm{pi} \ln \mathrm{pi}\right.$; where, $\mathrm{pi}=\mathrm{ni} / \mathrm{N}$; and ni=abundance of each species, $\mathrm{N}=$ total abundance of all species) were derived from the primary data separately for each layer following Misra (1968) and Shannon \& Weaver (1963) respectively. Berger and Parker Index $\left(D_{B P}=N \max / N\right.$ Where $\mathrm{Nmax}=$ is the number of individuals in the most species and $\mathrm{N}=$ is the total number of all individuals in all species) were weighted toward the abundance of the commonest species. For any information-statistics index, the maximum diversity of a community is found when all species are equally abundant. Community's actual diversity is measured by the formula: Evenness $(\mathrm{E})=\mathrm{H} / \mathrm{Hmax}$. Rank Abundance diagrams visually describe the allocation of individuals to species in communities.

The following formulae were used to compute different Phytosociological parameters:

$$
\% \text { Frequency }=\frac{\text { Total no. of quadrats in which the species occurred }}{\text { Total no. of quadrats studied }} \times 100
$$

Density $=\%$ Frequency $=\frac{\text { Total no.of quadrats in which the species occurred }}{\text { Total no. of quadrats studied }} \times 100$

Total no. of individuals of a species in all the quadrats Density $=$ Total no. of quadrats studied

Abundance $=\frac{\text { Total no. of individuals of the species in all the quadrats }}{\text { Total no. of quadrats in which the species occurred }}$

Relative Frequency $(\mathrm{RF})=\frac{\mathrm{T} \text { otalno } . \text { of occurrancesof a speciesin all the quadrats }}{\mathrm{T}}$

Relative Density $(\mathrm{RD})=\frac{\text { Total number of individuals of a species in all the quadrats }}{\text { Total number of individuals of all species in all quadrats }} \mathrm{X}$

Relative Dominance (R.Dom.) $\frac{\text { Total basal cover of each species in all quadrats }}{\text { Total basal cover of all species in all quadrats }}=\mathrm{x} 100$

$\mathrm{IVI}=$ Relative frequency + Relative density + Relative dominance

\section{Results}

Phytosociological study of plant/weed, which provide knowledge of the dynamics and relative importance of a species in a particular phytosocieties or across phytosocieties assume enough relevance in crop-weed ecosystem. It gives an appraisal of species through quantitative characters which allow effective weed management decision. From the results it appears that the total numbers of individual weeds (TNI) vary among the different species. The variable rate of frequency class distribution of weed flora of paddy fields of Baikunthpur block may be explained by a common biological explanation pattern which implies most dominant species appeared to colonize a new area appropriates a fraction of the available resources and by competitive interaction, preempts that fraction. The second species then preempts a similar fraction of the remaining resource and so on with further colonists. Data presented in Figure 1 reveals the overall frequency distribution of the studied weed flora of the paddy fields of Baikunthpur block. The frequency value ranged between $1-74 \%$.

Data presented in Figure 1 represents the frequency of occurance of different weed species under the prevailing environmental set up. The results reveal that Echinochloa colona, Cyperus iria and Cynodon dactylon showing $74 \%, 50 \%$ and $39 \%$ frequency and Marsillia minuta (33\%), Cyperus flavidus (33\%), Paspalum paspaloides (33\%) and Saccharum spontanaeum (41\%) were more frequent in occurance. The rarest of occurance were recorded by Alternanthera sessilis, Achyranthes aspera representing only $1 \%$ of frequency values among the various studied weed flora. Figure 2 represents the density value of the observed weed species in Baikunthpur block. The density value ranges between 0.04 to 3.3. Higher density values were recorded by Echinocloa colona, Cyperus iria, Eclipta prostrate, Cyperus flavidus. Highest and lowest density values were recorded by Echinocloa colona and Fimbristylis littoralis. Most of the plant species reflecting lower density values indicating single plant dominated community structure of the weed flora of the paddy field of Baikunthpur block (Figure 1). Therefore Echinocloa colona, Cyperus iria, Eclipta prostrate, Cyperus flaviduscan be considered as the dominant weed flora among the weed community prevailing over the paddy fields of Baikunthpur block.

Another important biodiversity indicator is the relative (proportional) abundance or degree of dominance of individuals among different species. This usually referred to as evenness or equitability and measures the extent to which species are equally represented in a community. There exists a strong correlation between structural diversity and species data pertaining to (Figure 3) reveals higher relative abundance for Cyperus haspan(3.75), 2.60 in Cyperus iria, 2.13 in Echinochloa colona, 3.18 in Ageratum conyzoides and 3.00 in Ammannia baccifera, Digitaria sanguinalis and Eclipta prostrata. Species showing very less abundance were Andropogon pumilis, Achyranthes aspera, Eragrostis pilosa, Ipomoea aquatica, Justicia simplex, Parthenium hysterophorus, Paspalum paspaloides, Polygonum plebejum and Sida cordifolia.

\section{Relative frequency}

The relative frequency distribution values represented in Table 1 reflects significant level of variation among the different observed weed species. The relative frequency distribution represented in Table 1 reflects lower values. This therefore indicates that relative proportion of occurrence of species to each other is very low.

\section{Relative density}

Data presented in Table 1 reflects significant level of variation in the relative density value among the 43 weed species of Baikunthpur block of Korea District. Relative density value was found to be highest for Cyperus flavidus which clearly reflects the single plant dominating feature among the weed community of the paddy fields of Baikunthpur block. 


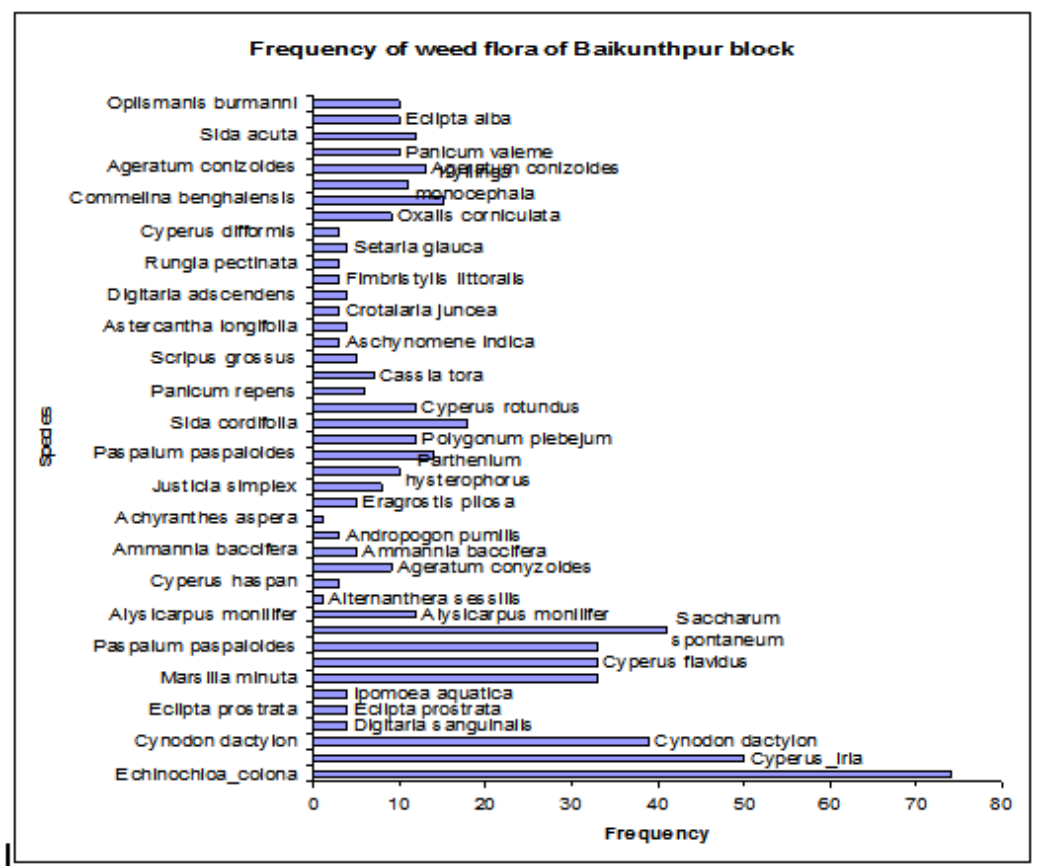

Figure I Frequency of weed flora of paddy field of Baikunthpur block.

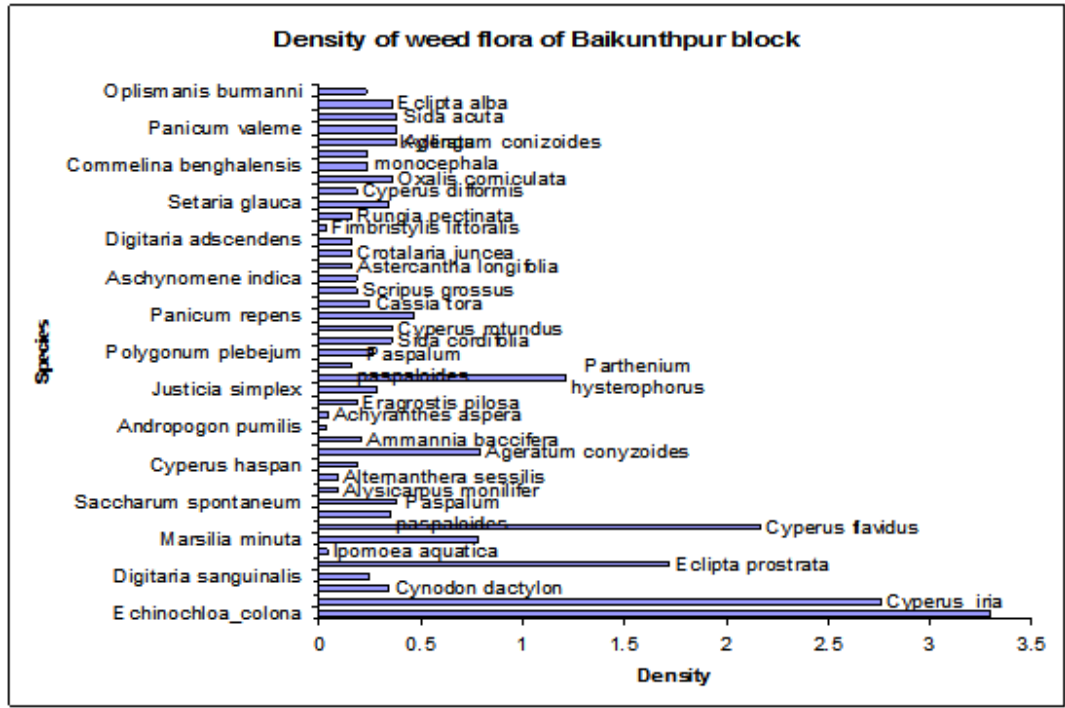

Figure 2 Density of weed flora of paddy field of Baikunthpur block.

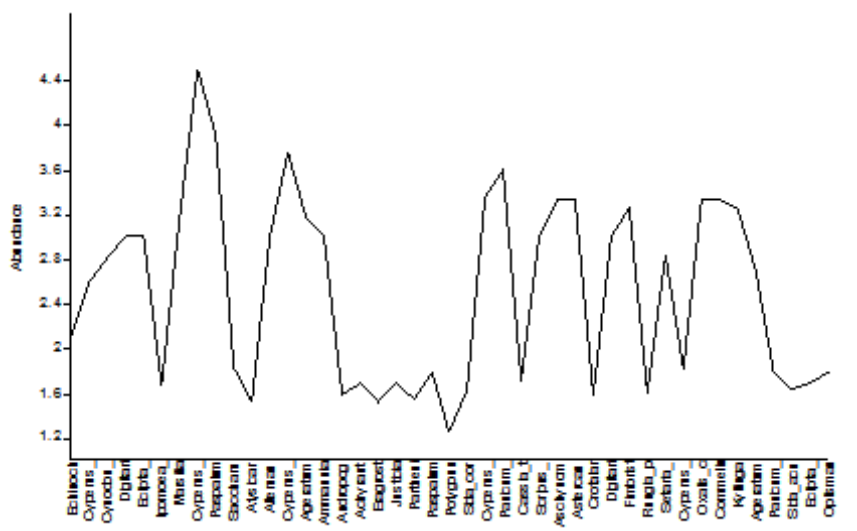

Figure 3 Variation in the abundance of the studied weed flora. 
Table I Importance value index (IVI) of different weeds plant species of Baikunthpur (Koria district)

\begin{tabular}{|c|c|c|c|c|c|}
\hline & & Relative density & Relative frequency & Relative dominance & I.V.I. \\
\hline & & (R.D.) & (R.F.) & (R.Dom) & (R.D.+R.F.+R.Dom) \\
\hline I & Echinochloa colona & 1.07319 & 6.1527 & 38.1674 & 45.39329 \\
\hline 2 & Cyperus iria & 1.175 & 8.29619 & 31.5562 & 41.02739 \\
\hline 3 & Cynodon dactylon & 0.7319 & 0.9167 & I.104I & 2.7527 \\
\hline 4 & Digitaria sanguinalis & 0.2927 & 0.7639 & $1.696 \mathrm{I}$ & 2.7527 \\
\hline 5 & Eclipta prostrata & 0.8783 & 0.3819 & 0.1293 & I.3895 \\
\hline 6 & Ipomoea aquatica & 0.1463 & 0.3055 & 0.7903 & I.242| \\
\hline 7 & Marsilia minuta & 1.8296 & 1.5863 & 16.0289 & 19.4448 \\
\hline 8 & Cyperus flavidus & 6.2927 & $\mathrm{I} .5278$ & 22.3611 & 30.1816 \\
\hline 9 & Paspalum paspaloides & 1.4638 & 0.9167 & 13.3065 & 15.687 \\
\hline 10 & Saccharum spontaneum & 0.763 & 0.113 & 10.446 & 11.322 \\
\hline 11 & Alysicarpus monilifer & $0.805 I$ & 0.9617 & 12.6872 & 14.454 \\
\hline 12 & Alternanthera sessilis & 1.017 & 0.291 & 10.0987 & II. .4067 \\
\hline 13 & Cyperus haspan & 0.768 & 0.143 & 20.436 & 21.347 \\
\hline 14 & Ageratum conyzoides & 1.017 & 3.069 & 21.208 & 25.294 \\
\hline 15 & Ammannia baccifera & 0.763 & 1.228 & 18.5 & 20.491 \\
\hline 16 & Andropogon pumilis & 0.2195 & 1.2987 & $|3.635|$ & 15.1533 \\
\hline 17 & Achyranthes aspera & 0.04391 & 0.3055 & 20.0377 & $20.387 I I$ \\
\hline 18 & Eragrostis pilosa & 0.2927 & I.0695I & 19.5748 & 20.93701 \\
\hline 19 & Justicia simplex & 0.763 & 0.12 & 17.416 & 18.299 \\
\hline 20 & Parthenium hysterophorus & 0.763 & 0.12 & 9.416 & 10.299 \\
\hline 21 & Paspalum paspaloides & 1.272 & 0.744 & 11.415 & $13.43 \mid$ \\
\hline 22 & Polygonum plebejum & 1.017 & 0.4 & 12.175 & 13.592 \\
\hline 23 & Sida cordifolia & 0.3659 & 0.4583 & 14.5029 & $|5.327|$ \\
\hline 24 & Cyperus rotundus & 0.1463 & 0.9167 & $|2.45| \mid$ & $|3.5| 4 \mid$ \\
\hline 25 & Panicum repens & 0.8783 & 0.7639 & 13.1459 & $|4.788|$ \\
\hline 26 & Cassia tora & 0.5123 & 0.9167 & $|7.256|$ & $|8.685|$ \\
\hline 27 & Scripus grossus & 1.543 & 0.71 & $|5.58|$ & 17.834 \\
\hline 28 & Aschynomene indica & 1.272 & 0.597 & 10.689 & 12.558 \\
\hline 29 & Astercantha longifolia & 2.544 & 2.725 & 12.249 & 17.518 \\
\hline 30 & Crotalaria juncea & 1.017 & 0.415 & 16.983 & 18.415 \\
\hline 31 & Digitaria adscendens & 0.391 & 0.6111 & I I.0978 & 12.0999 \\
\hline 32 & Fimbristylis littoralis & 1.272 & 1.183 & 9.481 & 11.936 \\
\hline 33 & Rungia pectinata & 0.3855 & 0.9167 & 12.9746 & 14.2768 \\
\hline 34 & Setaria glauca & 0.8783 & 0.9931 & I I.0777 & $|2.949|$ \\
\hline 35 & Cyperus difformis & 0.2195 & 0.6875 & 14.5807 & I5.4877 \\
\hline 36 & Oxalis corniculata & 0.4391 & I.I459 & 13.437 & 15.022 \\
\hline 37 & Alsicarpus monilifev & 0.508 & 0.132 & 10.658 & II.298 \\
\hline 37 & Commelina benghalensis & 0.763 & 0.355 & 12.385 & 13.503 \\
\hline 38 & Kyllinga monocephala & 0.508 & 0.57 & | 4.0774 & 15.1554 \\
\hline
\end{tabular}


Table Continued..

\begin{tabular}{|c|c|c|c|c|c|}
\hline \multirow{2}{*}{ S.No. } & \multirow{2}{*}{ Plant species } & Relative density & Relative frequency & Relative dominance & I.V.I. \\
\hline & & (R.D.) & (R.F.) & (R.Dom) & (R.D.+R.F.+R.Dom) \\
\hline 39 & Ageratum conizoides & 1.017 & 0.136 & 17.576 & 18.729 \\
\hline 40 & Panicum valeme & 0.763 & 0.612 & 14.124 & 15.499 \\
\hline 41 & Sida acuta & 1.526 & 0.306 & 11.682 & $13.5 \mid 4$ \\
\hline 42 & Eclipta alba & I.78। & 0.839 & 16.227 & 18.847 \\
\hline 43 & Oplismanis burmanni & 0.508 & 0.207 & 20.0564 & $20.77 \mid 4$ \\
\hline
\end{tabular}

\section{Relative dominance}

Relative dominance of weed species reflected higher values which therefore indicate their relative population strength among the diverse weed community.

\section{Importance value index}

The highest IVI value of Echinocloa colona, Cyperus iria and Cyperus flavidus was most dominant among the observed weed community. The lowest IVI values represented by Cyanodon dactylon, Digitaria sanguinalis, Eclipta prostrata, Ipomea aquat ica reflects that they are the rarest species in the weed community. Thus Echinocloa colona is the dominant weed species of the concerned study site. The IVI value ranged between 1.2421 to 45.39329 . Our findings were similar with the earlier findings of Holm et al ${ }^{10}$ Cluster analysis of weed flora of Baikunthpur block on the basis of density reflected numerous clustering among different species indicating the closer density value, strong association between different weed species and homogenous distribution of species in their natural habitat (Figure 4). Data presented in Table 2 reflects the results of correlation analysis among the Phytosociological attributes of weed flora of Baikunthpur Block of Korea district. From the correlation study it appears that density is significantly $(\mathrm{P}>0.05)$ and positively correlated with frequency and relative frequency. IVI value was found to be strongly correlated with frequency and relative dominance at $5 \%$ level of significance. Further frequency is positively correlated with relative frequency.

\section{Diversity indices}

Diversity is the index of the ratio between the number of species and the important value of an individual. Shannon index values (314) were found to be considerably higher for the concerned study site. Thus, Viola surpense is the most dominant species of the study area. The Evenness index value is very low for the Baikunthpur block which therefore indicates the species are clumped together within their habitat and therefore not evenly spaced (Table 3).

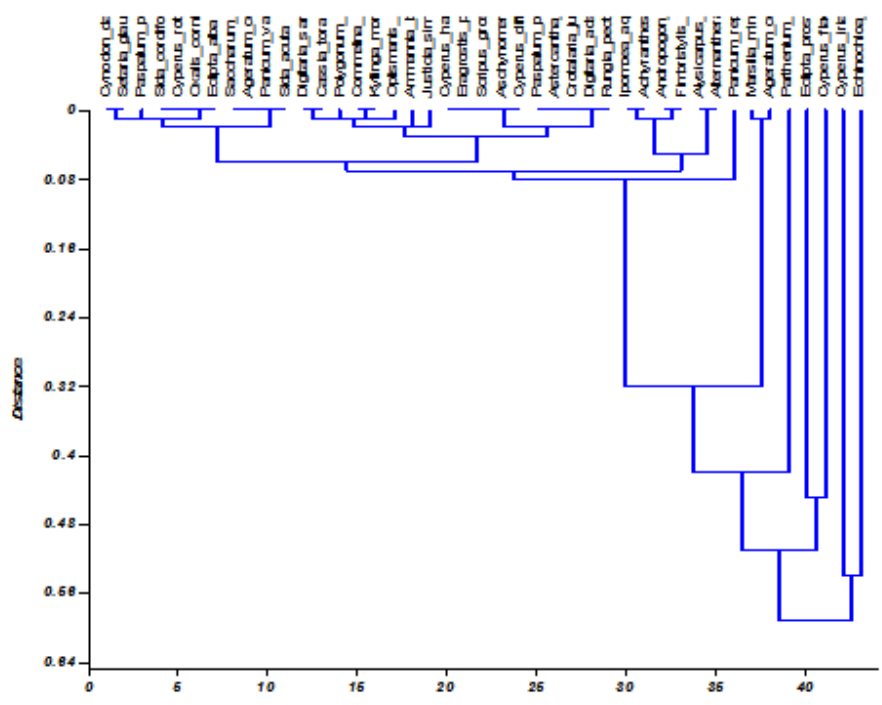

Figure 4 Dendrogram analysis of weed flora of Baikunthpur block.

Table 2 Correlation analysis between phytosociological attributes of weed flora of different study sites of Baikunthpur area of Koria district

\begin{tabular}{lllllll}
\hline & Density & Frequency & Ab & RD & RF & Rel Dom \\
\hline Frequency & $\mathbf{0 . 7 3 8 *}$ & & & & & \\
Abundance & 0.161 & 0.086 & & & & \\
RD & 0.39 & 0.276 & 0.437 & & & \\
RF & $\mathbf{0 . 7 4 8 *}$ & $\mathbf{0 . 6 3 9}$ & 0.112 & 0.171 & & \\
Rel Dom & 0.556 & 0.482 & -0.029 & 0.229 & $\mathbf{0 . 6 6 2}$ & \\
IVI & 0.648 & 0.552 & 0.048 & 0.34 & $0.757 *$ & $\mathbf{0 . 9 8 3 *}$
\end{tabular}


Table 3 Diversity indices value of weed flora in Baikunthpur block of Koria district

\begin{tabular}{ll}
\hline Dominance_D & 0.06997 \\
Shannon_H & 3.14 \\
Simpson_I-D & 0.93 \\
Evenness_e^ $^{\wedge} \mathrm{H} / \mathrm{S}$ & 0.5372 \\
Menhinick & 9.348 \\
Margalef & 13.76 \\
Equitability_」 & 0.8348 \\
Berger-Parker & 0.156 \\
\hline
\end{tabular}

\section{Discussion}

The habitat is of immense value to mankind because the modern material civilization is entirely based on the exploitation and utilization of the existing resources drawn from the environment and created through human efforts. The controlling mechanisms of biodiversity in different ecosystems are mentioned by the theory of species richness which considers resource availability and disturbance as factors for structuring plant communities. The concept of species diversity relates simply to "richness" of a community or geographical area in species. At the simplest level of examination, species diversity corresponds to the number of species present. Species diversity is considered to be an important attribute of community organization and allowed comparison of the structural characteristics of the communities. It is often related to community dynamics stability, productivity, integration, evolution, structure and competition The idea of displacement of one species through competition with other is net prime importance. Observations described above clearly indicate that Echinochloa colona and Cyperus iria have been found to be most frequently distributed weed species in all the study sites sampled. Density-wise also, these two species were found the most populated species. Almost the same picture is seen with abundance also. This shows that data on density, frequency and abundance do not vary much with respect to cropping seasons and study sites. The high number of weeds identified in this study could be attributed to the presence of a large weed seed bank in the soil that must have been deposited from previous years. Weeds have higher seed production that is easily dispersed through different ways with variable dormancy resulting in germination by flushes over a long period. ${ }^{11}$ The persistent weed species give a severe competition to paddy crop and reduce the agricultural output.

The exhibition of a high level of persistence of the most important species of weeds as fore-runners in all their Phytosociological attributes could not be unconnected to their similarity in their family's morph orgy and development attributes. Most of the weed species with the highest density, frequency and abundance were of the grass family and sedges. These weeds have high fecundity producing hundreds of thousands of seeds during single growing season reproduce through vegetative propagules and seeds and have vegetative mimicry with crops in addition to long-time seed dormancy. ${ }^{11,12}$ From the two years observations, it was found that weed growth occurs within forty one days after paddy sowing/planting and they may propagate by seeds and propagules or by both. The perennial weeds create the most serious problem in paddy fields. Major weeds produce a large number of seeds, which may remain in soil and serve as soil seed bank for the next cropping season. It can be emphasized that major weeds should be controlled at proper time to check reduction in paddy yield and they must be removed before flowering and fruiting to reduce the production of seeds that remain as soil seed bank for the following years. ${ }^{13-20}$ For proper management of weed one should remember that most of the weeds flower and fruit during June to November. Weeding has to be done before this period to avoid the gradual development of weed bank in the soil under dormant condition which in further time period would germinate and propagate at faster rate to reduce the agricultural output. ${ }^{21-24}$

\section{Conclusion}

The present study was conducted as a first ever attempt from the study area to explore and identify the weeds of paddy crop. This will help the farmers and agriculturists of the study area to identify the weeds and thus help in planning a suitable strategy for their control as these weeds compete with paddy crop for resources and hence reduce its yield. They also affect the quality of germplasm and cause enormous loss to the farmers.

\section{Acknowledgements}

None.

\section{Conflict of interest}

The author declares no conflict of interest.

\section{References}

1. GOI. Ministry of Finance, Government of India. Economic Survey 2011-2012; 2012.

2. Savary S, Castilla NP, Elazegui FA, et al. Multiple effects of two drivers of agricultural change, labour shortage and water scarcity on rice pest profiles in tropical Asia. Field Crops Res. 2005;91:263-271.

3. Dangwal LR, Singh A, Singh T, et al. Effects of weeds on the yield of Maize crop in tehsil Nowsera. International journal of Current Research. 2011;3(7):69-70.

4. Patil PS, Ahirrao YA, Dusing YA, et al. Role of crop weeds in traditional medicines in Buldhana district (Maharastra). Life sciences leaflets. 2010;10:261-272.

5. Singh S, Singh G, Singh VP, et al. Effect of establishment methods and weed management practices on weeds and rice in rice-wheat cropping system. Indian Journal of Weed Science. 2005;37(1-2):51-57.

6. Rao AN, Nagamani A. Available technologies and future research challenges for managing weeds in dry seeded rice in India. In: Proceeding of the 21st Asian Pacific Weed Science Society Conference 2 to 6th October, Sri Lanka; 2007.

7. Sharma BM, Kachroo P. Flora of Jammu and plants of neighborhood. Bishen Singh Mahendra Pal Singh. India; 1983.

8. Swami A, Gupta BK. Flora of Udhampur. Bishen Singh Mahendra pal Singh, India; 1998 pp. 1-455.

9. Kaul MK. Weed flora of Kashmir valley. Journal of Economic and Taxonomic Botany, additional series. India: Scientific Publishers; 1986. p. $1-422$.

10. Holm GL, Plucknett DL, Pancho JV, et al. The World's Worst Weeds: Distribution and Biology. USA: East west center press Honolulu Hawaii; 1977.. 1-621.

11. Akobundu IO. Weed Science in the Tropics. Principles and Practices. USA: John Wiley \& Sons Ltd; 1987. p. 1-538.

12. Zimdahl RL. Fundamentals of Weed Science. 3rd ed. USA: Academic press; 2007. p. 1-689. 
13. Pandeya SC, Shah DP. Phytosociology and seasonal weed succession of paddy field and a comparison there of with adjoining abandoned arable land at Raipur (M.P.). Proc Natl Acad Sci India. 1966;36:190-98.

14. Tripathi RS, Misra R. Phytosociological studies of the crop weed association at Varanasi. Jour Ind Bot Soc. 1971;50:142-152.

15. Shukla RV, Diwakar MC. Aquatic and amphibious weeds of Bilaspur (M.P.). Plant Protection Bulletin. 1973;1\&2:15

16. Gupta OP. Survey of weed flora of Tarai region U.P. Cab dev J Sci Technol. 1966;B 4:86-96.

17. Rao AN, Dagar JC, Dubey PS. Phyto-allelopathic potentials of $P$. hysterophorus Linn. Ind J Weed Sci. 1977;9(1):24-30.

18. Kondap S, Chandrashekhar Rao MJ, Venkatachari A. Phenological studies of certain weeds. Proc J Sws APAU Weed Sc Cong Hyderabad. 1977. p. $226-227$
19. Singh SK. Weed flora of paddy crop in Jaunpur (U.P.). Oryza. 1979;6:113-114.

20. Sharma BN. A phytosociological study of a weed community in fallow land in the semi-arid zone of India. Weed Science. 1981;29(3):287-291.

21. Pathak T. Ecophysiological studies of some weeds with special reference to Commelina benghalensis. India: University of Saugor Sagar; 1981.

22. Verma A. Ecological studies of some weeds of Central India with special reference to Alysicarpus longifolia Wight. India: University of Saugor Sagar; 1981.

23. Shivnath, Gupta SK. Phytosociological studies on weeds competing with Barley (Hordeum vulgare) crop. Ind J of Ecol. 1982;9:59-63.

24. Khare, Archana, Shrivastava SP, et al. Weed flora of paddy crop of Banda district. Flora and Fauna. 2004;10(1):15-18. 